focus on German Studies.

https://journals.uc.edu/index.php/fogs

(ISSN 1076-5697)

focus

on German Studies

Issue 28 (2021)

Book Review

Culture in the Third Reich

By Moritz Föllmer, Translated by Jeremy Noakes and Lesley Sharpe, Oxford

University Press, 2020. 336. \$25.95.

Rachel Wilson

Boston University

How to Cite: Wilson, Rachel. "Book Review: Culture in the Third Reich". focus on German Studies 28, no. 28, 2021, pp.239-246. DOI: 10.34314/FOGS2021.00019. 


\section{Culture in the Third Reich}

\section{By Moritz Föllmer, Translated by Jeremy Noakes and Lesley Sharpe, Oxford University Press, 2020. 336. \$25.95.}

Rachel Wilson

In his impressive monograph, Moritz Föllmer details the creation, implementation, and evolution of National Socialist culture from the Weimar Republic to the end of World War II. Föllmer explains that National Socialist culture was shaped by 19th century imperialism and German nationalism, the immediate impact of World War I, and the failures and perceived excesses of Weimar. Culture in the Third Reich, he writes, reflected Hitler's political goals and personal tastes, as well as the ensuing rivalry among his most loyal followers, from top-ranking Nazi officials like Rosenberg, Goebbels, and Speer to local Gauleiters. Arguably Föllmer's more important contribution to the field, however, is that National Socialist culture was not simply forced upon a passive German citizenry. Rather, everyday people eagerly participated in popular culture. For conservative, middle-class Germans in particular, Nazi culture represented community, belonging, and a shared ethos. While culture in the Third Reich was shaped by those in power, it was enthusiastically embraced by many.

Through the lens of culture, Föllmer provides a useful chronology of the Nazis' rise, seizure, and consolidation of power. Beginning in Weimar, he details the sense of anxiety 
and isolation many Germans experienced after the First World War and the key role the German middle-class played in establishing a National Socialist culture in the 1920s. Prior to the rise of the NSDAP, many middle-class Germans expressed growing concerns about international influence on German politics and culture. In their mind, "diversity" had caused inflation, mass unemployment, a broken parliamentary system, and violence in the streets. Therefore, middle-class values were confirmed, rather than challenged, by contacts with National Socialism. Locating the roots of National Socialist culture in the 1920s is also important because Nazism drew not only on imperialist and nationalistic trends of the Kaiserreich, but importantly, from Weimar itself. While most scholars note the cosmopolitanism of Weimar, Föllmer argues "the nationalism that emerged in Imperial Germany and grew progressively more radical in the 1920s was as much a part of 'Weimar' as, for example, the painting and literature of New Objectivity" (16). In the 1920s, Germans reasserted their nationalism following the humiliating defeat in World War I and the seemingly threatening influence of an increasingly heterogenous nation.

Enter Hitler and the NSDAP, who skillfully translated this sense of cultural dislocation into political action rooted in a vision of German national resurgence. National Socialism "brought existing tendencies sharply into focus, but gave them a clear direction and invested them with an extra utopian dimension" (25). Throughout the 1930s, the Nazis effectively manipulated these anxieties to serve their own racialized political agenda. For 
instance, a middle-class distaste for modernist art developed into outrage over the destructive Jewish influence on German culture. That National Socialist and bourgeois culture overlapped contributed significantly, as "the Nazis were not obviously different from the majority of middle-class lovers of culture, who still focused primarily on 19th century works and had few regrets about modernists, left-wingers, and Jews being excluded" (76). The difference being that now bourgeois culture was defined racially, by those approved to be members of the Volksgemeinschaft. This interplay between top-down decisions and bottom-up participation is crucial to understanding the success of National Socialist culture.

Föllmer further explains that the movement promised not only ideological gains, but also material ones. For those who participated, a new culture presented Germans with opportunities. The regime granted Nazi artists, for instance, jobs, commissions, awards, and benefits. Like visual artists, filmmakers and actors benefitted from collaboration with the regime through organizations such as the German Film Academy. Yet Culture in the Third Reich importantly reminds the reader that conformity was more than just opportunism; for many, it was about conviction. This is evidenced by another aspect of National Socialist culture: everyday Germans' participation in dissolving institutions, marginalizing and excluding enemies, and violence. Beyond the propaganda and effective use of mass media, Föllmer highlights the role terror played in the creation, consolidation, and imposition of National Socialist culture. 
As the regime legalized anti-Semitic ideology through increasingly radical laws and policies, National Socialist culture reflected that escalation. Throughout the 1930s, science legitimized popular prejudices about these groups. Much like artists who participated, the regime provided professional opportunities for academics through medical experiments, ethnography, and research into defining “Jewishness” scientifically. In the late 1930s, National Socialist culture was also used to advance imperialist motivations, as the regime utilized propaganda in an effort to make Germans more willing to go to war. Early victories in the war further served as evidence of German cultural superiority and racial hierarchy, as the Nazis combined imperialism, occupation, and art looting. As the war continued and increasingly looked grim for the Nazis, however, claims to the cultural superiority of National Socialism crumbled.

While certain aspects of culture in the Third Reich remained consistent from the 1920s through the 1940s (nationalism, anti-Semitism, cultural superiority), one of the strengths of Culture in the Third Reich is the evidence provided to illustrate that National Socialist culture was not a monolithic style; rather, one that changed constantly and evolved to serve shifting goals of the regime. During Weimar, for example, the Nazis utilized völkisch styles that highlighted German nationalism and traditional values. Here, Föllmer relies on an impressive source base to include examples as varied as Heimat films and musicals, news reports of battleships that touted the superiority of German engineering, and 
the popularity of football and sports culture. After the immediate seizure of power in 1933, the regime shaped a culture defined in opposition to Weimar. The impoverished, starving images of unemployed veterans on the streets of Berlin, for instance, were contrasted with travel photography from Strength through Joy holidays, emphasizing the health—physical, racial, economic_ — of the new Germany. Throughout the 1930s, National Socialist culture furthered popular prejudice about Jews, "asocials," and other enemies of the state through a variety of media, such as the 1937 Degenerate Art exhibition in Munich and the rewriting of textbooks.

National Socialist culture evolved further in the late 1930s as the regime made preparations for war. This was demonstrated through increased public displays of imperial ambitions in architecture, such as the German pavilion at the Paris world exhibition in 1937 and Speer's proposed, though never realized, "Reich Capital of Germania." Unlike the völkisch styles of the 1920s and early 1930s, the regime's dominant influences became neoclassical, ancient Greco-Roman buildings as symbols of permanence and power. The regime had new goals; therefore, National Socialist culture adapted to best reflect that. Waging war was crucial for the fulfillment for National Socialism's prophecy. As the war raged on, German cultural superiority was imposed abroad, as imperialism was not simply concerned with occupying a territory politically and economically, but culturally as well. The Paris Opera, for instance, "now draped in swastika flags, performed more works 
by Beethoven, Mozart, and Wagner than before” (187). Yet despite these early triumphs, National Socialist culture shifted once more, as the realities of Germany's inescapable loss affected the production of culture, such as the physical destruction of cities that halted performances and the stoppage of print media due to paper shortages. The impressive level of detail Föllmer provides effectively illustrates the evolution of National Socialist culture as well as its importance to the regime.

While Föllmer skillfully analyzes Weimar and the Third Reich, his findings abruptly stop there. He writes that "after 1945 it was again possible to distinguish between German and National Socialist culture" (270). Arguments such as these reflect a Stunde Null approach to the Nazi past, and this reviewer wonders how accurate that claim can be when many former Nazis held positions of power in the Federal Republic. Would not the pervasive nature of National Socialist culture, as well as the active role of both everyday Germans and former NSDAP members in West Germany, indicate it would take a while to eradicate National Socialism's cultural hold? Though the institutions, organizations, and individuals that defined Nazi culture may have been dissolved, the participation of millions of ordinary Germans in that culture lingered well into the postwar period. Furthermore, what constituted "German" culture after 1945, as East and West were created, at least initially, in the image of their occupiers?

Culture in the Third Reich, however, does not claim to extend into the period 
following WWII. Therefore, Föllmer successfully accomplishes what he sets out to do. His work sheds important light on the role culture played in the Third Reich beyond propaganda, coercion, and terror. National Socialist culture demonstrated political control, imperialism, and racism; but it also reflected popular participation in dictatorship, as evidenced by the "less overtly Nazi aspect" of culture in the Third Reich (3). Overall, this monograph is well-researched, persuasive, and full of fascinating anecdotes, cultural references, and insights. While Modern German historians would benefit most from the sharp analysis found in this book, additional features, such as a glossary of key figures and dates, make Föllmer's work accessible to non-specialists as well. 